Wilfrid Laurier University

Scholars Commons @ Laurier

Biology Faculty Publications

Biology

Winter 2-2019

\title{
Identification of the alternative oxidase gene and its expression in the copepod Tigriopus californicus
}

\author{
Allison McDonald \\ Wilfrid Laurier University, amcdonald@wlu.ca \\ Carly E. Tward \\ Wilfrid Laurier University, gold8730@mylaurier.ca \\ Willie Cygelfarb \\ Wilfrid Laurier University, cyge3600@mylaurier.ca \\ Jaspreet Singh \\ Wilfrid Laurier University, jasp14@gmail.com
}

Follow this and additional works at: https://scholars.wlu.ca/biol_faculty

Part of the Biology Commons, Cellular and Molecular Physiology Commons, and the Comparative and Evolutionary Physiology Commons

\section{Recommended Citation}

McDonald, Allison; Tward, Carly E.; Cygelfarb, Willie; and Singh, Jaspreet, "Identification of the alternative oxidase gene and its expression in the copepod Tigriopus californicus" (2019). Biology Faculty Publications. 82.

https://scholars.wlu.ca/biol_faculty/82

This Article is brought to you for free and open access by the Biology at Scholars Commons @ Laurier. It has been accepted for inclusion in Biology Faculty Publications by an authorized administrator of Scholars Commons @ Laurier. For more information, please contact scholarscommons@wlu.ca. 
1 Title: Identification of the alternative oxidase gene and its expression in the copepod

2 Tigriopus californicus

3 Author names and affiliations: Carly E. Tward, Jaspreet Singh, Willie Cygelfarb and

4 Allison E. McDonald

5 Department of Biology, Wilfrid Laurier University, 75 University Ave. W., Waterloo,

6 Ontario, N2L 3C5, Canada

7 Corresponding author: Allison E. McDonald, amcdonald@wlu.ca; Department of

8 Biology, Wilfrid Laurier University, 75 University Ave. W., Waterloo, Ontario, N2L 3C5,

9 Canada

10

11

12

13

14

15

16

17

18

19

20 


\section{Abstract}

22 In addition to the typical electron transport system (ETS) in animal mitochondria

23 responsible for oxidative phosphorylation, in some species there exists an alternative

24 oxidase (AOX) pathway capable of catalyzing the oxidation of ubiquinol and the

25 reduction of oxygen to water. The discovery of AOX in animals is recent and further

26 investigations into its expression, regulation, and physiological role have been

27 hampered by the lack of a tractable experimental model organism. Our recent DNA

28 database searches using bioinformatics revealed an AOX sequence in several marine

29 copepods including Tigriopus californicus. This species lives in tidepools along the west

30 coast of North America and is subject to a wide variety of daily environmental stresses.

31 Here we verify the presence of the AOX gene in T. californicus and the expression of

32 AOX mRNA and AOX protein in various life stages of the animal. We demonstrate that

33 levels of the AOX protein increase in T. californicus in response to cold and heat stress

34 compared to normal rearing temperature. We predict that a functional AOX pathway is

35 present in T. californicus, propose that this species will be a useful model organism for

36 the study of AOX in animals, and discuss future directions for animal AOX research.

38 Key Words: arthropod, electron transport system, environmental stress, mitochondria,

39 protein isolation, respiration, tide-pool

40 


\section{Introduction}

43 The Alternative Oxidase (AOX) Pathway

$44 \quad$ Cellular respiration in animal cells takes place in the mitochondria via the

45 electron transport system (ETS). The ETS is comprised of multi-subunit complexes and

46 mobile electron carriers in the inner membrane of the mitochondria (Genova, 2014).

47 Four complexes, (I, II, III, and IV), and the mobile carriers ubiquinone/ubiquinol and

48 cytochrome c, shuttle electrons through the system to the final electron acceptor oxygen

49 (Genova, 2014). At the same time, several of these complexes move protons from the

50 matrix to the intermitochondrial membrane space and result in a proton motive force

51 (PMF) across the inner mitochondrial membrane (Genova, 2014). This PMF is used by

52 complex V (ATP synthase), and as protons flow back into the matrix through this

53 enzyme, ATP is synthesized through the process of oxidative phosphorylation (Genova, 54 2014).

$55 \quad$ Many animals also contain additional enzymes capable of putting electrons into

56 and/or removing electrons from the ETS (McDonald and Gospodaryov, 2018). One such

57 enzyme is the alternative oxidase (AOX), a terminal quinol oxidase that catalyzes the

58 oxidation of ubiquinol and the reduction of oxygen to water (McDonald and

59 Vanlerberghe, 2004; McDonald, 2008). In contrast to cytochrome c oxidase, which is

60 comprised of nuclear and mitochondria encoded subunits, the AOX is encoded by a

61 single nuclear gene (McDonald, 2008). The AOX protein is composed of four helices

62 and several conserved amino acid residues that are important for its enzymatic function

63 (McDonald, 2008). Use of the AOX pathway causes electrons to bypass complexes III 
64 and IV and results in cyanide-resistant respiration (Rogov et al., 2014). As AOX is non-

65 proton pumping (in contrast to complexes I, III, and IV), it does not contribute directly to

66 the proton motive force (PMF), and the energy associated with electron transport is

67 dissipated as heat (McDonald, 2008). Therefore, AOX is viewed as energetically

68 inefficient.

69 AOX in Animals

70 AOX has been identified in several animal species due to the presence of AOX

71 DNA or mRNA sequences in public molecular databases (McDonald and Vanlerberghe,

72 2004; McDonald et al., 2009). Recent database searches have revealed the presence

73 of AOX DNA or mRNA in the phyla Ctenophora, Platyhelminthes, Arthropoda,

74 Tardigrada, Scalidophora, Brachiopoda, and Rotifera for the first time (McDonald and

75 Gospodaryov, 2018). Experimental evidence for the expression of AOX mRNA exists for

76 the sponge Ephydatia muelleri, and the molluscs Anadara ovalis, Crassostrea gigas,

77 Crassostrea virginica, and Mercenaria mercenaria (McDonald et al., 2009; Liu and Guo,

78 2017). Thus far, the only investigation of changes in AOX expression due to

79 environmental conditions has been the use of quantitative PCR (qPCR) to investigate

80 AOX transcript levels in the bivalves Crassostrea gigas and Diplodon chilensis which

81 increased in response to hypoxia and anoxia (Sussarellu et al., 2012; Yusseppone et

82 al., 2018).

83

The bulk of information about the AOX of animals exists at the level of genes or

84 transcripts. The only reports of naturally occurring AOX proteins present in animals are

85 from the brine shrimp Artemia franciscana and the Pacific oyster Crassostrea gigas; 
86 AOX proteins in these species are $\sim 35 \mathrm{kDa}$ in size (Rodriguez-Armenta et al., 2018).

87 Knowledge of other animal AOX proteins is limited to studies that have taken advantage

88 of heterologous expression systems, therefore it is difficult to determine whether the

89 molecular masses of AOX reported reflect reality in vivo. For example, the expression of

90 the AOX from the sea squirt Ciona intestinalis produced a functional enzyme capable of

91 oxygen consumption of $42 \mathrm{kDa}$ that was targeted to mitochondria in human kidney cells,

92 mice, and fruit flies (Hakkaart et al., 2006; El-Khoury et al., 2013; Kemppainen et al.,

93 2014). ). Heterologous expression of the Pacific oyster AOX has also occurred in the

94 yeast Saccharomyces cerevisiae (Robertson et al., 2016). It is clear that there is a need

95 for an animal model that naturally expresses the AOX protein. The importance of finding

96 a suitable organism for the study of animal AOX is important as typically used model

97 systems (i.e. mouse and fruit fly) do not contain a naturally occurring AOX and therefore

98 cannot be studied (McDonald et al., 2009). No information exists regarding the post-

99 translational regulation of an animal AOX. In contrast to Complexes I-IV of the ETS,

100 there is no evidence that AOX exists as part of any respiratory supercomplex (Schertl

101 and Braun, 2014). The activation and inhibition kinetics of animal AOX proteins is also

102 unknown. Information on the characteristics of animal AOX proteins is needed, both due

103 to the desire for basic biological knowledge, and the realization that this knowledge is

104 required to assess the efficacy and safety of proposals to use AOX as a gene therapy

105 tool in humans for the treatment of mitochondrial diseases (El-Khoury et al., 2014). This

106 gap in our knowledge exists because to date animals known to contain AOX gene

107 sequences are often expensive to grow and culture in the lab, take up large amounts of

108 laboratory space, and do not have rapid life cycles which makes them impractical and 
109 challenging for scientific study. In addition, research efforts have been hampered by the

110 existence of few genetic, molecular biology, and biochemical protocols and tools that

111 are available for use in these animals. It is clear that a worthy endeavor is to find a

112 useful AOX containing animal that is inexpensive to culture, has a rapid generation time,

113 takes up little space, and for which protocols and tool development is possible. In this

114 paper we assert that the intertidal copepod Tigriopus californicus meets all of these

115 criteria and can be used as a model system for the investigation of an animal AOX

116 protein.

117 Tigriopus californicus

$118 T$. californicus is an intertidal species of copepod found on the Pacific coast of

119 North America that inhabits rock pools (Burton and Lee, 1994). Due to T. californicus'

120 intertidal habitat, these animals are exposed to ever changing environmental stressors

121 including temperature, salinity, and oxygen levels (Burton and Lee, 1994) and

122 presumably have mechanisms in place to deal with such challenges. $T$. californicus has

123 a short generation time ( 2-4 weeks depending on rearing temperature)(Hong and

124 Shurin, 2015), small space needs, and genetically divergent populations that can be

125 cross-bred in the laboratory (Burton \& Feldman, 1981). A strong argument for using $T$.

126 californicus as a model organism in ecotoxicology and environmental genomics has

127 been made based on the above characteristics (Raisuddin et al., 2007). In addition, a

128 protocol and tool exists for the suppression of gene transcription using RNA interference

129 in this species (Barreto et al., 2015b). 
$130 T$ T. californicus has been used to investigate the mechanisms of speciation and

131 incompatibilities in hybrid animals derived from mating different geographical

132 populations (Barreto et al., 2015a). Hybrid incompatibilities have been demonstrated to

133 have a negative impact on oxidative phosphorylation and the interaction between the

134 nuclear and mitochondrial genome encoded processes (Barreto et al., 2015a). This

135 incompatible hybridization causes mitochondrial dysfunction caused including inefficient

136 OXPHOS, a decrease in ATP biosynthesis, and increased ROS production (Barreto et

137 al., 2015a). An investigation into the bioenergetics of T. californicus is therefore

138 warranted at the level of the ETS by examining complexes I-IV and AOX.

139 In this study we confirm the presence of the AOX gene, the expression of AOX

$140 \mathrm{mRNA}$, and demonstrate that the AOX protein is present in the copepod T. californicus.

141 We believe this is the first step in establishing this copepod as a model species for

142 animal AOX research. By demonstrating that $T$. californicus is an effective model

143 species with experimental tools that are available, future research can examine the

144 physiological role of AOX in T. californicus and will explore questions about the

145 expression and regulation of AOX proteins in an animal system.

\section{Materials and Methods}

147 In silico identification of copepod AOX sequences

$148 \quad$ Molecular database searches using various animal AOX sequences in BLAST

149 (Basic Local Alignment Search Tool) using default settings at the National Center for

150 Biotechnology Information (NCBI) (http://www.ncbi.nlm.nih.gov/) (this was an iterative

151 process that used novel AOX sequences as they were discovered; full procedure as 
152 described in McDonald et al., 2009) identified several putative copepod AOX

153 sequences. DNA sequences were translated into protein sequences using the ExPASy

154 Translate Tool (http://web.expasy.org/translate/).

155 Laboratory Culturing Conditions of $T$. californicus

156 Animals were obtained from J\&L Aquatics Canada, Vancouver, British Columbia.

157 The animals arrived in a $\sim 150 \mathrm{~mL}$ bottle containing $\sim 1000-2000$ individuals at various life

158 stages. Animals used for DNA and RNA isolation were maintained in cultures of 20-200

159 individuals in $600 \mathrm{~mL}$ beakers containing $400 \mathrm{~mL}$ of seawater $(37.5 \mathrm{~g} / \mathrm{L})$ with a specific

160 gravity of 0.026 and grown at $21^{\circ} \mathrm{C}$ (room temperature) (Edmands and Deimler, 2004).

161 The salt water was made with Instant Ocean Salt and the specific gravity was tested

162 with the Instant Ocean Saltwater Aquarium Hydrometer (Instant Ocean, Blacksburg, VA,

163 USA). Each beaker was covered with the top plate of a petri dish to slow the rate of

164 evaporation. Beakers were placed in an incubator programmed to run on a 12 hour light

165 and 12 hour dark cycle. The animals were fed 4 drops of Reef Nutrition Phyto-Feast

166 Live Premium Phytoplankton (J\&L Aquatics Canada, Vancouver, British Columbia)

167 every other day for the entire culturing period. Preliminary experiments demonstrated

168 that our animals completed their life cycle faster at $15.0^{\circ} \mathrm{C}$, so a change in rearing

169 protocol occurred about 2 years into culturing T. californicus in the lab. Animals used for

170 protein isolations were cultured in $400 \mathrm{~mL}$ beakers filled with $250 \mathrm{~mL}$ of salt water $(41.7 \mathrm{~g}$

171 of Instant Ocean salt per $1 \mathrm{~L}$ of MilliQ filtered water) at $15^{\circ} \mathrm{C}$ using a 12 hour light and 12

172 hour dark cycle. The copepods were fed once a week with $0.01 \mathrm{~g}$ of Tetramin fish food

173 (Nutrafin Basix) and $0.005 \mathrm{~g}$ of Spirulina powder (EarthRise) in $50 \mathrm{~mL}$ of salt water

174 added to each habitat. The water in each habitat was changed weekly in order to 
175 prevent the build-up of moulted exosketetons and waste in the beakers. Animals used in

176 temperature experiments were acclimated to $15^{\circ} \mathrm{C}$ (normal growth temperature) for $2-4$

177 weeks before being exposed to $6^{\circ} \mathrm{C}$ (cold) or $28^{\circ} \mathrm{C}$ (hot) for 24 hours (acute treatment)

178 or 1 week (chronic treatment) before collection for protein isolation.

179 DNA and RNA isolation and AOX Gene and Transcript analysis

180 Primer Design

181 Gene specific primers for the $T$. californicus 551 bp AOX cDNA fragment

182 (JW502496) identified in the NCBI database were designed using the Primer3 program

183 (http://frodo.wi.mit.edu/primer3). Custom primers were then synthesized (Invitrogen Life

184 Technologies, Carlsbad, CA, USA) for use in PCR and RT-PCR protocols (Table 1).

185 Three different forward and reverse primer sets were created in order to generate cDNA

186 products ranging from 200-500bp; multiple primer sets were designed in case one or

187 more sets proved unsuccessful in producing a product.

188 Collection and preparation of copepods

189 In order to collect the copepods from the cultures for the isolation of DNA and RNA

190 the animals were strained out from the water using Miracloth (pore size: $22-25 \mu \mathrm{m}$ )

191 (Merck KGaA, Darmstadt, Germany). Once the water was completely drained from the

192 beaker, the copepods were washed several times with clean salt water and quickly

193 transferred to a pre-weighed Eppendorf tube, the mass of the animals was determined

194 ( $200 \mathrm{mg}$ ), and the tube was frozen in liquid nitrogen. The frozen copepods were then

195 removed from the Eppendorf tube and ground into a fine powder using a previously

196 autoclaved and chilled pestle and mortar. The powdered sample was kept cold by

197 grinding under liquid nitrogen. 
Isolation of nucleic acids and amplification parameters

For the extraction of DNA and RNA from $T$. californicus Trizol reagent proved most effective (Invitrogen Life Technologies, Carlsbad, CA, USA) and the protocol was

201 conducted as per the manufacturer's instructions. Once the nucleic acids were

202 successfully isolated from $T$. californicus and quantified using spectrophotometry, PCR

203 and reverse transcriptase (RT)-PCR were conducted in order to amplify the targeted

204 AOX sequence. PCR was conducted with $5 \mu \mathrm{g}$ of $T$. californicus DNA using $0.5 \mu \mathrm{L}$ iTaq

205 DNA polymerase (Bio-Rad Laboratories Ltd., Mississauga, ON, CA), $2 \mu \mathrm{L}$ of each 10 $206 \mu \mathrm{M}$ forward and reverse primer, $2 \mu \mathrm{L}$ of $10 x$ PCR buffer, $2 \mu \mathrm{L}$ of dNTP mix, and $1.5 \mu \mathrm{L}$

207 of nuclease-free water in $20 \mu \mathrm{L}$ total volume. The thermal cycler was set for 1 cycle of 2

208 minutes at $94^{\circ} \mathrm{C}$ for initial denaturation, 40 cycles consisting of: denaturation for 20

209 seconds at $94^{\circ} \mathrm{C}$, annealing for 10 seconds at $58^{\circ} \mathrm{C}$, and extension for 30 seconds at

$21068^{\circ} \mathrm{C}$, followed by 1 cycle of final extension for 10 minutes at $68^{\circ} \mathrm{C}$ and the final soak

211 cycle at $4^{\circ} \mathrm{C}$ held indefinitely, until the sample was removed from the thermocycler (Bio-

212 Rad Laboratories Ltd., Mississauga, ON, CA).

213 RT-PCR was conducted using the Access RT-PCR Introductory System (Promega

214 Corporation, Madison, WI, USA) with $2 \mu \mathrm{g}$ of total DNase treated RNA in $50 \mu \mathrm{L}$

215 reactions containing $10 \mu \mathrm{L}$ AMV/Tfl $5 x$ reaction buffer, $1 \mu \mathrm{L}$ dNTP mix, $2 \mu \mathrm{L}$ of each 10

$216 \mu \mathrm{M}$ forward and reverse primer, $2 \mu \mathrm{L}$ of $25 \mathrm{mM} \mathrm{MgSO}_{4}, 1 \mu \mathrm{L}$ AMV RTase, $1 \mu \mathrm{L}$ Tfl DNA

217 polymerase, and $29.5 \mu \mathrm{L}$ nuclease-free water. The thermal cycler was set for first strand

$218 \mathrm{cDNA}$ synthesis consisting of 45 minutes at $45^{\circ} \mathrm{C}$ for reverse transcription and 2

219 minutes at $94^{\circ} \mathrm{C}$ for AMV RT inactivation. This was followed by 40 cycles of

220 denaturation for 30 seconds at $94^{\circ} \mathrm{C}$, annealing for 1 minute at $60^{\circ} \mathrm{C}$, and extension for 
2212 minutes at $68^{\circ} \mathrm{C}$, followed by 1 cycle of final extension for 7 minutes at $68^{\circ} \mathrm{C}$ and the

222 final soak cycle held at $4^{\circ} \mathrm{C}$, until the sample was removed from the thermocycler (Bio-

223 Rad Laboratories Ltd., Mississauga, ON, CA).

224 The amplification products were separated using DNA gel electrophoresis using a

$2251.2 \%$ agarose gel containing $1 \mathrm{~mL} 50 \times$ Tris-acetate-EDTA (TAE) buffer, $49 \mathrm{~mL}$ nuclease-

226 free water $\left(\mathrm{dH}_{2} \mathrm{O}\right)$, and $0.60 \mathrm{~g}$ agarose powder run in a tank with $1 \mathrm{x}$ TAE running buffer.

$2275 \mu \mathrm{L} 1 \mathrm{~kb}$ or $100 \mathrm{bp}$ DNA ladder (GeneDirex, USA) was loaded in the first lane of the

228 gel, followed by 5-10 $\mu \mathrm{L}$ of each PCR or RT-PCR reaction combined with 6X DNA

229 loading buffer in subsequent lanes. Gels were run at $80-120 \mathrm{~V}$ for 45 minutes and

230 stained with ethidium bromide in order to visualize the DNA under UV light (VersaDoc

231 400) (Bio-Rad Laboratories Ltd., Mississauga, ON, CA).

232 Isolation of Proteins from Copepods

233 For each protein extraction, approximately $0.05-0.10 \mathrm{~g}$ of copepods were isolated

234 from their habitats by filtration using a $100 \mu \mathrm{m}$ filter (Fisherbrand) and placed in an

235 Eppendorf tube. Various combinations of different volumes of SDS-PAGE sample buffer

$236(350-500 \mu \mathrm{L})$ and $20 \mu \mathrm{L}$ of $\beta$-mercaptoethanol solution were pipetted into each

237 Eppendorf tube. Each sample was sonicated (Omni International Inc.) for 10 seconds at

238 a frequency of $6 \mathrm{kHz}$ and/ or homogenized to extract the proteins from the copepods.

239 The Precellys 24 lysis and homogenization machine (Bertin Technologies) was used to

240 perform the homogenization of copepod tissue. The homogenization processes

241 consisted of adding beads into each sample, loading the samples into the machine, and

242 3D bead-beating for 30 seconds at 5000rpm. These various combinations were used in 
243 order to identify the optimal conditions for protein isolation from our laboratory grown

244 copepods.

245 Protein Analysis: Gel Electrophoresis

246 Protein samples were analyzed using reducing SDS-PAGE and Western blotting.

247 For gel electrophoresis, a 15 well mini-PROTEAN TGX Stain-Free gel (Bio-rad), was

248 loaded with $15 \mu \mathrm{L}$ of each copepod sample. In order to determine the molecular weight

249 of the proteins in our samples, two wells were loaded with $5 \mu \mathrm{L}$ of the Precision Plus

250 Protein WesternC Standards (Bio-rad). A yeast sample expressing the Pacific oyster

251 alternative oxidase (Robertson et al., 2006) served as a positive control in order to verify

252 the cross-reactivity of the AOX antibody with our copepod samples. A negative control

253 blot was run using proteins isolated from the algal food source to rule out the possibility

254 of an algal AOX being detected in our copepod samples. Following the loading of the

255 wells the gel was run at a constant voltage (200V) for 35 minutes. After the run was

256 complete, the gel was visualized using a VersaDoc (Bio-rad, USA) so an image could

257 be taken to visualize protein loading. For protein gels using our temperature experiment

258 samples, proteins in each sample were quantified using Quick Start Bradford Protein

259 Assay using bovine serum albumin standards and a spectrophotometre. Each sample

260 consisted of $20 \mu \mathrm{g}$ of protein added to each lane.

261 Protein Analysis: Western Blot

262 The Trans-Blot Turbo Transfer System (Bio-rad) was used to transfer the

263 proteins onto a nitrocellulose membrane in 3 minutes using Trans-Blot Transfer Medium

264 (Bio-rad). Following protein transfer, the membrane was placed in 5\% dry milk in $10 \mathrm{~mL}$ 
265 of 1 X TBS-T on a shaking platform for 1 hour. The membrane was then subsequently

266 washed three times in TBS-T. $4 \mu \mathrm{L}$ of the primary AOX antibody (Plant AOX1/2, Cat. \#

267 ABIN3197483, Agrisera Antibodies) was then added to $20 \mathrm{~mL}$ of $1 \mathrm{X}$ TBS-T for 1 hour

268 (dilution 1: 10,000). Following this, the membrane was again washed three times (15

269 minutes, 10 minutes, and 10 minutes) with TBS-T. The membrane was then incubated

270 in $2 \mu \mathrm{L}$ secondary antibody, a goat anti rabbit lgG (Cat. \# ABIN101988, Agrisera

271 Antibodies, dilution 1:25,000), and $2 \mu \mathrm{L}$ of the Precision Protein StrepTactin HRP

272 Conjugate (Bio-rad) in $20 \mathrm{~mL}$ of $1 \mathrm{x}$ TBS-T for 1 hour followed by three washes in $1 \mathrm{X}$

273 TBS-T. It was subsequently placed in a mixture of luminol/enhancer and peroxide buffer

274 solution from the Immun Star Western C Chemiluminescent kit (Bio-rad) in a 1:1 ratio

275 for 5 minutes. The membrane was then placed in the VersaDoc, and the

276 chemiluminescent signal was detected and imaged.

277 Results

278 Identification of putative AOX sequences in copepods

279 A molecular database search using a BLAST (Basic Local Alignment Search

280 Tool) at the National Center for Biotechnology Information (NCBI) revealed the

281 presence of putative AOX sequences in 14 different copepod species (Table 2). The

282 copepod species are representatives of 3 different copepod orders and 12 different

283 families (Table 2). The predicted AOX proteins all contained at least 2 or more of the 4

284 iron-binding motifs (Table 2) containing conserved glutamate and histidine residues

285 required for the enzyme to be functional (McDonald et al., 2009). AOX DNA and mRNA 
286 in copepods are present in multiple developmental stages, both sexes, and various

287 habitats around the world (Table 2).

288 In silico analyses of the Tigriopus californicus AOX sequence

289 A molecular database search revealed a putative T. californicus AOX DNA

290 sequence of 551 bp (Figure A.1). The predicted protein from T. californicus was a

291 partial sequence, however 3 out of the 4 iron binding motifs containing conserved

292 glutamate and histidine residues required for the enzyme to be functional (McDonald et

293 al., 2009) were present (Figure A.1). From previous studies, the C-terminal motif N-P-

294 [YF]-X-P-G-[KQE], was determined to be diagnostic for animal AOX proteins (McDonald

295 et al., 2009). T. californicus demonstrates a high level of motif conservation in the region

296 of the protein mentioned above (i.e. N- P-F-E-K-G-K) (Figure A.1).

297 Molecular analyses of the T. californicus AOX

298 Trizol reagent proved to be effective in isolating RNA from the copepods and

299 allowed us to proceed with RT-PCR. All three AOX primer sets yielded cDNA fragments

300 of the expected sizes (Figure 1). Proteins were successfully isolated from $T$. californicus

301 using $0.05 \mathrm{~g}$ of copepods and 350 or $500 \mu \mathrm{L}$ of SDS-PAGE sample buffer containing $\beta$ -

302 mercaptoethanol and using various combinations of sonication and homogenization

303 (Figure A.2). The T. californicus AOX was recognized by a plant AOX antibody and was

$304 \sim 50 \mathrm{kDa}$ in size (Figure 2). The antibody failed to cross-react with the AOX protein

305 likely present in the algae provided to the copepods as food (Figure A.3). Previous

306 studies have demonstrated that algal AOXs contain features that differ from those of

307 other organisms (e.g. extended N-terminus and other insertion/deletions) (Nemanis et 
308 al., 2013). We therefore expected that a plant AOX antibody would not cross-react with

309 the algal AOX.

310 Response of AOX Protein Levels to Temperature Treatments

311 Copepods were acclimated to $15^{\circ} \mathrm{C}$ for $2-4$ weeks and then subjected to one of

312 three different temperatures $\left(6,15\right.$, or $\left.28^{\circ} \mathrm{C}\right)$ for 24 hours or 1 week and then sampled.

313 Protein gels demonstrated that equal protein loading had occurred (Figure A.4 and A.5).

314 Western blots indicate that AOX protein levels are low under control conditions (24

315 hours at $15^{\circ} \mathrm{C}$ ), but AOX levels are higher after 24 hours of exposure to $6^{\circ} \mathrm{C}$ and $28^{\circ} \mathrm{C}$

316 (Figure 3). Similarly, AOX protein levels are low under control conditions (1 week at

$31715^{\circ} \mathrm{C}$ ), but $\mathrm{AOX}$ levels are higher after 1 week of exposure to $6^{\circ} \mathrm{C}$ and $28^{\circ} \mathrm{C}$ (Figure 4).

318 Discussion

319 Discovery of AOX in Copepods and the Phylum Arthropoda

320 We have shown that AOX is in the genomes of multiple species of copepods

321 from around the world that inhabit a wide variety of ecological niches (Table 2.) The first

322 reports of AOX from arthropods were in the brine shrimp Artemia franciscana and

323 putative sequences from other members of the Chelicerata, Hexapoda, and Crustacea

324 (Rodriguez-Armenta et al., 2018; McDonald and Gospodaryov, 2018). It was previously

325 hypothesized that AOX was not present in arthropods due to a gene loss event

326 (McDonald et al., 2009), however, the above data refute this hypothesis.

$327 \quad$ Based on information gathered using bioinformatics tools, the copepod $T$.

328 californicus contains an AOX sequence (Figure A.1, Table 2). Our next goal was to 
329 determine whether the AOX gene of $T$. californicus is expressed in the animal. RT-PCR

330 using RNA isolated from pooled developmental stages of the organism verified that

331 AOX mRNA is expressed in the copepod (Figure 1). This represents the first AOX

332 mRNA detected experimentally in any arthropod using gene specific primers for AOX.

333 In order to verify that the AOX sequence recovered from the arthropod $T$.

334 californicus was from this animal and not a contaminant (e.g. from a microbial symbiont

335 or pathogen) the animal's $551 \mathrm{bp} \mathrm{cDNA}$ sequence was translated to its predicted protein

336 sequence and was found to possess the C-terminal region N-P-F-E-K-G-K (Figure A.1).

337 This C-terminal motif is of particular interest because it is characteristic of only animal

338 AOXs and is different from the C-terminal regions observed in plants and fungal species

339 (McDonald et al., 2009).

340 We wished to confirm that AOX protein was detectable in T. californicus. Reducing

341 SDS-PAGE followed by Western blotting with a commercial plant AOX1/2 antibody

342 detected a protein of $\sim 50 \mathrm{kDa}$ in our copepod samples (Figure 2). Heterologously

343 expressed AOX proteins from Ciona intestinalis and Crassostrea gigas are $35-42 \mathrm{kDa}$ in

344 size (Hakkaart et al., 2006; Robertson et al., 2016). The AOX protein of Artemia

345 franciscana is between 25 and $37 \mathrm{kDa}$ on Western blots using the anti-AOX

346 Sauromatum guttatum monoclonal antibody (Rodriguez-Armenta et al., 2018). It is

347 expected that the food source (Spirulina) would contain AOX as it is an algae, however,

348 the AOX antibody did not recognize a protein in this sample (Figure A.3).

349 Finally, we wished to determine if AOX protein levels would change in response to 350 an environmental stressor. The copepods are normally reared at $15^{\circ} \mathrm{C}$ and have been 
351 cultured at this temperature for several years and have likely adapted to this growth

352 temperature over many generations in our lab. We therefore selected $15^{\circ} \mathrm{C}$ as our

353 control temperature and exposed treatment groups to either $6^{\circ} \mathrm{C}$ (cold) or $28^{\circ} \mathrm{C}$ (hot) for

354 an acute time period of 24 hours or a chronic time period of 1 week prior to sampling the

355 animals. Animals grown at $15^{\circ} \mathrm{C}$ exhibited very low levels of detectable AOX protein

356 (Figures 3 and 4). In contrast, animals grown at $6^{\circ} \mathrm{C}$ or $28^{\circ} \mathrm{C}$ exhibited higher levels of

357 AOX protein after 24 hours of exposure (Figure 3) or 1 week of exposure (Figure 4).

358 Similar to what we report here, an increase in AOX protein levels in response to cold

359 stress has been reported in a variety of plants (McDonald, 2008). In addition, AOX1

360 protein levels sharply increase in response to heat stress in the green alga

361 Chlamydomonas reinhardtii (Zalutskaya et al., 2015). Unfortunately, no other studies

362 have examined the effects of biotic or abiotic stressors on AOX protein levels in any

363 animal that naturally possesses the enzyme. The only other investigation of a native

364 AOX from an animal is a Western blot confirming its presence in the brine shrimp

365 Artemia franciscana (Rodriquez-Armenta et al., 2018). Our finding is therefore the first

366 to demonstrate that the levels of a native AOX protein in an animal change in response

367 to an environmental stressor.

368 The Power of T. californicus as an Experimental System to Examine AOX

369 T. californicus represents an emerging model organism for research because of

370 its abundance, wide geographic distribution, ease of manipulation in laboratory settings,

371 and its ecological relevance due to its position in marine food webs (Raisuddin et al.,

372 2007). Lab grown cultures of $T$. californicus can be maintained for many generations

373 and are relatively inexpensive to house. We were able to isolate copepod DNA and 
374 RNA using Trizol reagent and present a protocol here for successfully isolating proteins

375 from whole animals. Coupled with newer techniques such as RNA interference (RNAi)

376 (Barreto et al., 2015), it is clear that many experimental tools can be used to answer

377 questions about $\mathrm{AOX}$ in this organism.

378 Based on our results, we can begin to ask questions about the genes involved in

379 regulatory pathways that control transcript expression levels in response to

380 environmental changes, developmental stages, and gender. Analysis of AOX

381 expression levels can be conducted by subjecting $T$. californicus to a variety of

382 environmental stressors such as alterations in salinity and temperature (Lauritano et al.,

383 2012; Zhang et al., 2013) in order to observe patterns of AOX gene expression under

384 varying environmental conditions. The environmental stress of fluctuating salinity levels

385 is a key stressor to T. californicus and has been noted to affect the expression of a

386 variety of genes in the copepod (Burton and Lee, 1994; Van Aken et al., 2009). We

387 have demonstrated that AOX protein levels increase in $T$. californicus in response to

388 temperature stress, however, at this time it is not known why $T$. californicus has the

389 gene for and produces AOX protein. It is thought that the AOX pathway provides

390 metabolic flexibility and gives the organism the ability to survive under a multitude of

391 environmental stressors (Vanlerberghe, 2013). In addition, this system also represents

392 an opportunity to study the post-translational regulation of the AOX protein in $T$.

393 californicus.

$394 \quad$ Future Direction and Applications 
Knowledge about animal AOX also has applications in human and animal

396 medicine. Comparative research may aid in the treatment of diseases caused by

397 parasitic protists, where AOX is a current target of drug design (May et al., 2017). AOX

398 research could lead to the development of anti-parasitic drugs that can be used to kill

399 parasitic copepods that live on the skin of economically valuable fish species. Humans

400 do not contain $\mathrm{AOX}$, and the information gathered from our research may eventually

401 contribute to the treatment of mitochondrial dysfunctions and disorders in humans using

402 AOX gene therapy (El-Khoury et al., 2013; Fernandez-Ayala et al., 2009; Hakkaart et

403 al., 2006; Kemppainen et al., 2014). Heterologous expression systems provide a

404 potential route of expression to rescue electron flow and test hypotheses in order to

405 mitigate the deleterious complications involved with respiratory chain dysfunctions (such

406 as Parkinson's, diabetes mellitus, and deafness) (Hakkaart et al, 2006; Kemppainen et

407 al., 2014), but this requires extensive knowledge about the regulation of AOX gene

408 expression and the post-translational regulation of the AOX protein.

409 We believe that $T$. californicus is an excellent model system in which to study

410 AOX. These animals can be used to study the physiological role of AOX and to test

411 functional hypotheses about the enzyme. This will lead to an increase in our knowledge

412 of AOX in general and contribute to the assessment its future applications in healthcare

413 and aquaculture.

\section{Acknowledgements}

415 This work was supported by the Natural Science and Engineering Research

416 Council of Canada (NSERC), the Canada Foundation for Innovation Leaders 
417 Opportunity Fund, the Ontario Research Fund, and the Faculty of Science Students'

418 Association (FOSSA) of Wilfrid Laurier University.

419 The authors report no conflict of interest.

420 Figure Captions

421 Figure 1. Reverse-transcriptase PCR products using T. californicus AOX gene specific

422 primers with DNase treated RNA. Lane 1, $5 \mu \mathrm{L}$ 100bp DNA ladder; lane 2, $10 \mu \mathrm{L}$ AOX1

423 primer set product (232bp product size); lane 3, $10 \mu \mathrm{L}$ AOX2 primer set product (344bp

424 product size); lane 4, $10 \mu \mathrm{L}$ AOX3 primer set product (503bp product size); lane 5, 10

$425 \mu \mathrm{L}$ positive control from kit (323bp product size).

426 Figure 2. Detection of $T$. californicus AOX protein by reducing SDS-PAGE and Western

427 blotting using a plant AOX antibody. All T. californicus samples per well are $14 \mu \mathrm{L}$ of

428 protein samples derived from $0.05 \mathrm{~g}$ of copepods of mixed developmental stages

429 subjected to either sonication $(\mathrm{S})$, homogenization $(\mathrm{H})$, or a combination of the two $(\mathrm{H}$ \&

430 S). The protein sample buffer volume used (in microliters) is indicated by the number

431 below the isolation method. Ladder lanes contain $5 \mu \mathrm{L}$ of the Precision Plus Protein

432 Western C Standards. The positive control is $14 \mu \mathrm{L}$ of a protein sample from isolated

433 mitochondria from Saccharomyces cerevisiae overexpressing the Crassostrea gigas

434 AOX.

435 Figure 3. Detection of $T$. californicus AOX protein by reducing SDS-PAGE and Western

436 blotting using a plant AOX antibody under 24 hours exposure to different temperatures.

437 All T. californicus samples per well are $20 \mu \mathrm{g}$ of protein sample derived from $0.05-0.10 \mathrm{~g}$

438 of copepods of mixed developmental stages. Ladder lanes contain $5 \mu \mathrm{L}$ of the Precision 
439 Plus Protein Western C Standards. Temperature treatments are indicated above each 440 sample well.

441 Figure 4. Detection of $T$. californicus AOX protein by reducing SDS-PAGE and Western

442 blotting using a plant AOX antibody under 1 week exposure to different temperatures.

443 All $T$. californicus samples per well are $20 \mu \mathrm{g}$ of protein sample derived from $0.05-0.10 \mathrm{~g}$

444 of copepods of mixed developmental stages. Ladder lanes contain $5 \mu \mathrm{L}$ of the Precision

445 Plus Protein Western C Standards. Temperature treatments are indicated above each 446 sample well.

447 Figure A1. cDNA and predicted protein sequences of the AOX from Tigriopus

448 californicus. The highlighted region contains the C-terminal motif that is highly

449 conserved in animal AOX proteins.

450 Figure A2. Protein samples run on reducing SDS-PAGE. Ladder lanes contain $5 \mu \mathrm{L}$ of

451 the Precision Plus Protein Western C Standards. The positive control is $14 \mu \mathrm{L}$ of a

452 protein sample from isolated mitochondria from Saccharomyces cerevisiae

453 overexpressing the Crassostrea gigas AOX. All T. californicus samples per well are

$45414 \mu \mathrm{L}$ of protein samples derived from $0.05 \mathrm{~g}$ of copepods of mixed developmental

455 stages subjected to either sonication $(\mathrm{S})$, homogenization $(\mathrm{H})$, or a combination of the

456 two (H \& S). The protein sample buffer volume used (in microliters) is indicated by the

457 number below the isolation method.

458 Figure A3. Protein samples run on reducing SDS-PAGE and Western blotted using a 459 plant AOX antibody. The ladder lane contains $5 \mu \mathrm{L}$ of the Precision Plus Protein Western 460 C Standards. The algae lane contains a sample derived from the Spirulina used to feed 
461 the copepods. This sample was sonicated in the same manner as the copepod samples

462 and $14 \mu \mathrm{L}$ were loaded into the well.

463 Figure A4. Protein samples run on reducing SDS-PAGE. Ladder lanes contain $5 \mu \mathrm{L}$ of

464 the Precision Plus Protein Western C Standards. All T. californicus samples per well are

$46520 \mu \mathrm{g}$ of protein samples derived from $0.05-0.010 \mathrm{~g}$ of copepods of mixed

466 developmental stages subjected to 24 hours at the temperatures indicated above the

467 wells of the gel.

468 Figure A5. Protein samples run on reducing SDS-PAGE. Ladder lanes contain $5 \mu \mathrm{L}$ of

469 the Precision Plus Protein Western C Standards. All T. californicus samples per well are

$47020 \mu \mathrm{g}$ of protein samples derived from $0.05-0.010 \mathrm{~g}$ of copepods of mixed

471 developmental stages subjected to 1 week at the temperatures indicated above the

472 wells of the gel.

473

474

475

476

477

478

479

480 
486

487

488

489

490

491

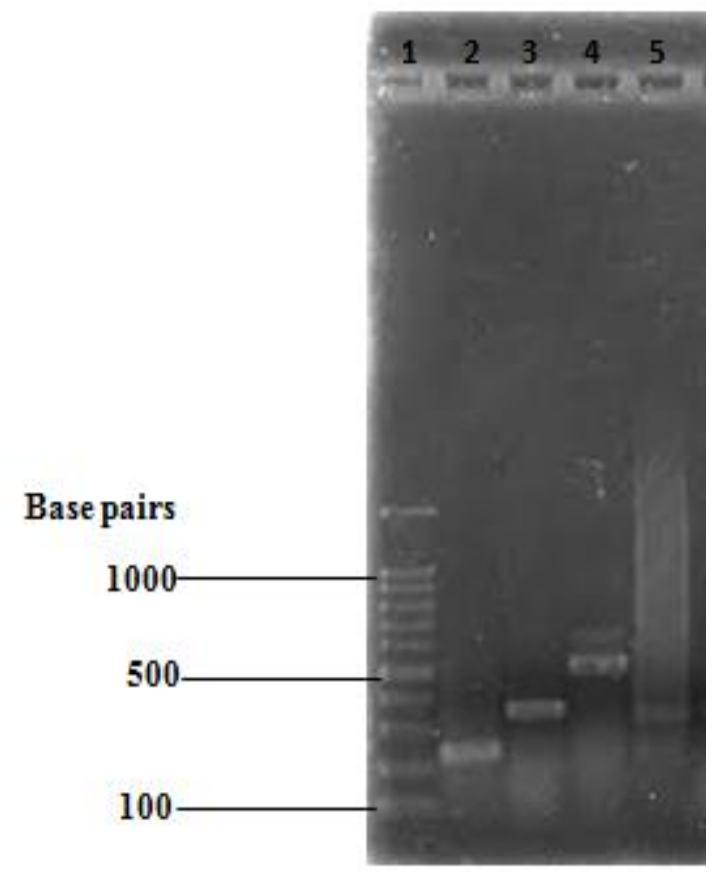

492

493

494

495

496

497 Figure 1.

498 


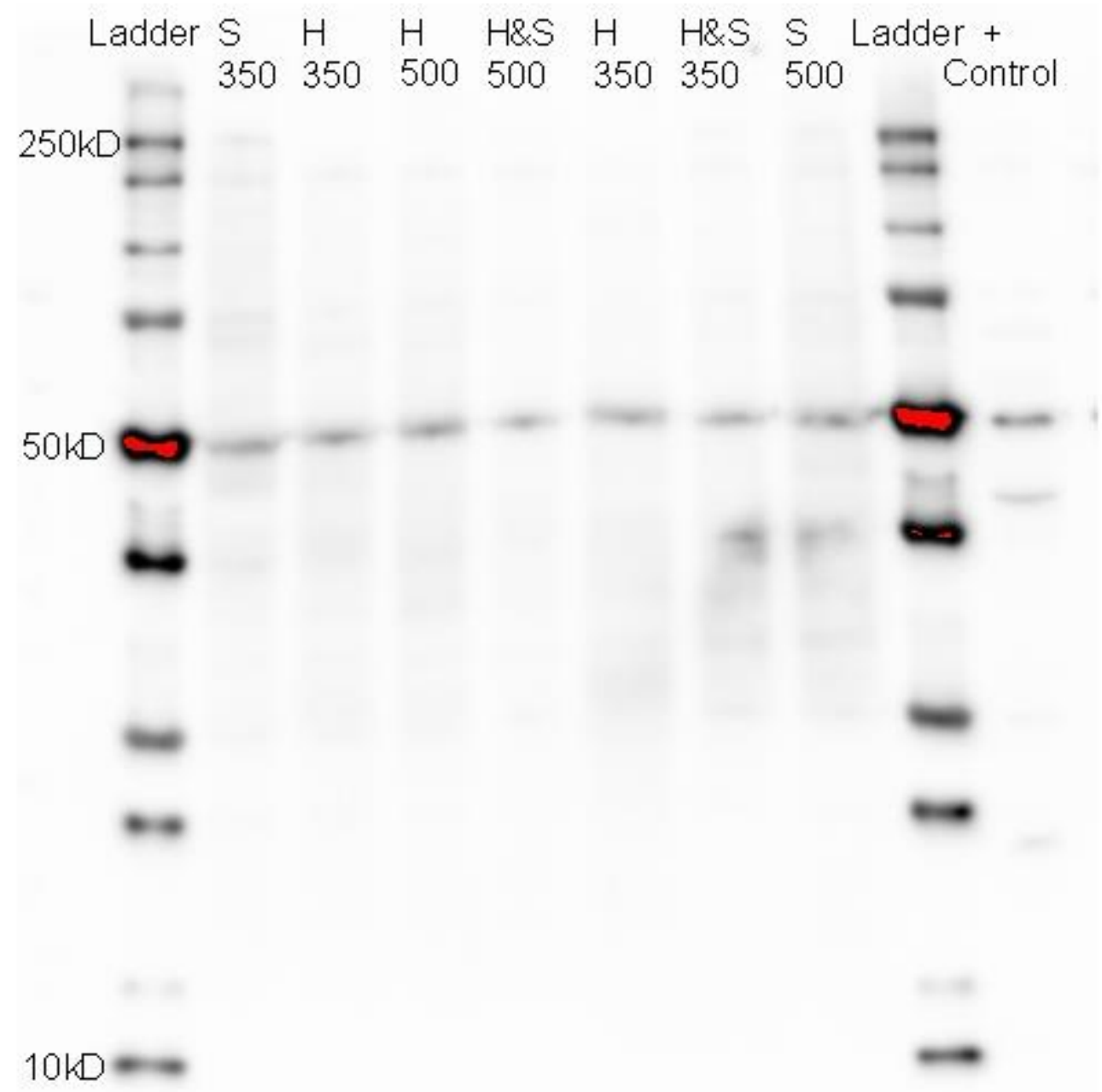

499

500

501

502 Figure 2.

503 


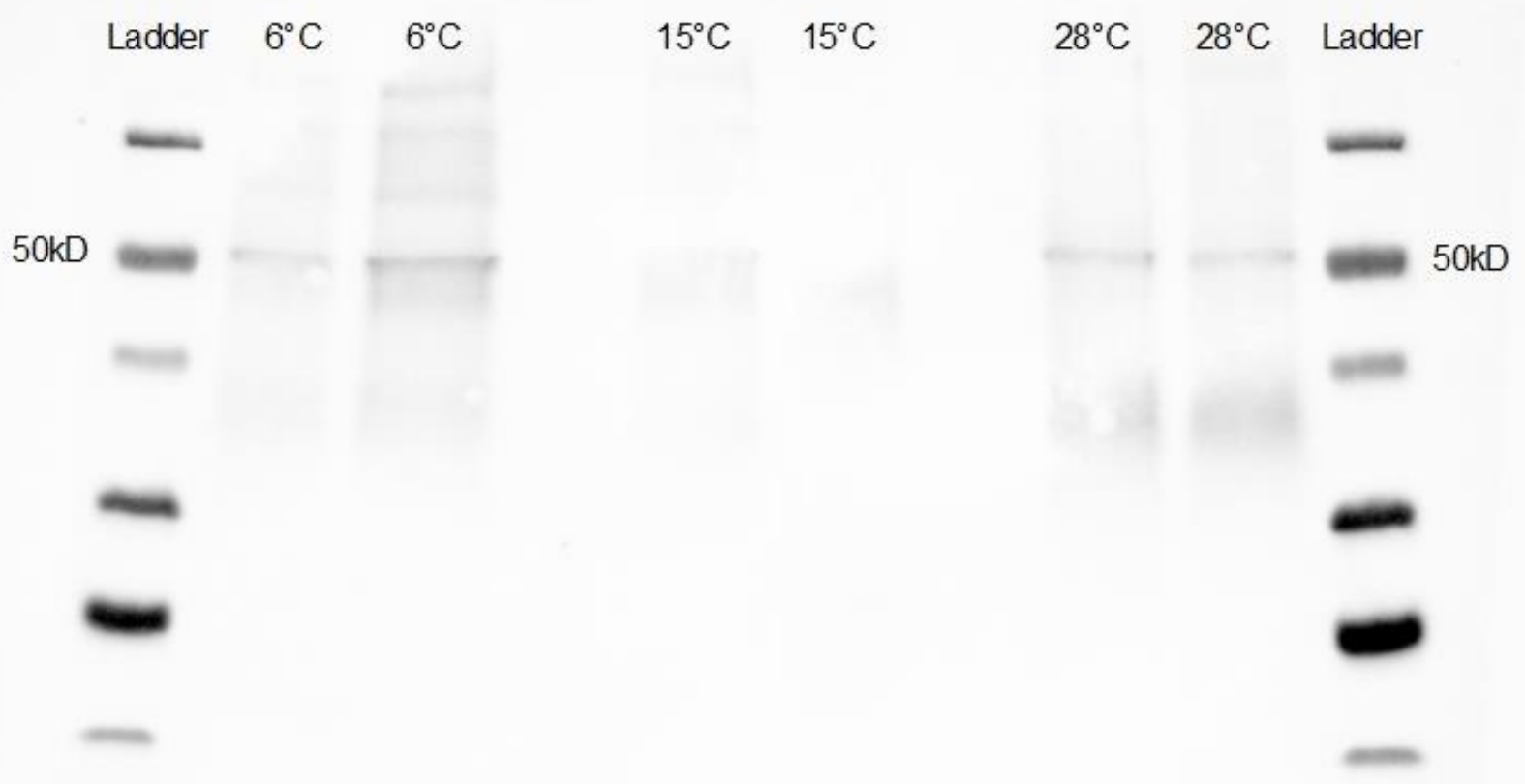

504

505

506

507

508

509

510 Figure 3.

511 
Ladder $\quad 6^{\circ} \mathrm{C} \quad 6^{\circ} \mathrm{C} \quad 15^{\circ} \mathrm{C} \quad 15^{\circ} \mathrm{C} \quad 28^{\circ} \mathrm{C} \quad 28^{\circ} \mathrm{C}$ Ladder

\section{$50 \mathrm{kD}$}
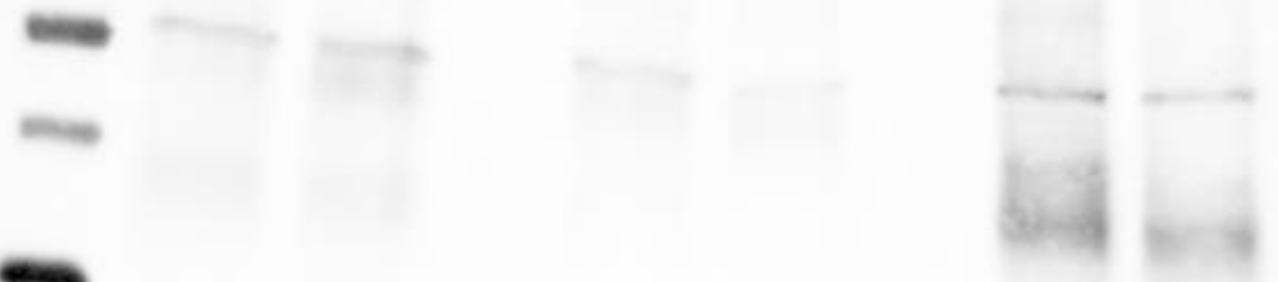

20ำ $50 \mathrm{kD}$

512

513

514

515

516

517

518 Figure 4.

519

520

521

522 
523 Tigriopus californicus 551bp cDNA sequence

524 GAATGCACGTGATCATGGATGGATCCACACTCTCCTGGAAGAAGCGGAGAATGAA

525 AGGATGCATCTGATGACCTTCATGCGACTCCGAAGACCCGGGCCCATTTTCCGAG

526 GCACCGTGATCCTGACTCAATGGCTGTTCACATTTACGTTCTCATTCGCTTACATAC

527 TGTCGCCCAATTTTTGCCACAGATTTGTTGGGTATTTGGAAGAGCAAGCAGTGGTC

528 ACTTACACTCACATCCTGGAAGAAATCGACGCAGGACGATTGCCCATGTGGAAGA

529 CCTTGCCAGCTCCGGAATTGGCCATCAAGTATTGGAGATTGCCCGAAGACGCCAA

530 GATGCGGGAAGTCATTTTGGCAATCCGAGCCGATGAAGCTCATCATCGGCTTGTG

531 AATCACACCCTTGGATCGATGGACCTCAAATCAGACAATCCTTTTGAGAAAGGGAA

532 ATAACTTTTGTCTTCGGCTCAGATACAAATTTAATGGTCAATAACAAGTATTCCATG

533 GTAAAAACGAACGGAGGTTGAGAAATATAAATAAATTGTCGAGTCTTTTC

534

535 Tigriopus californicus predicted protein sequence

536 NERMHLMTFMRLRRPGPIFRGTVILTQWLFTFTFSFAYILSPNFCHRFVGYLEEQAVVT

537 YTHILEEIDAGRLPMWKTLPAPELAIKYWRLPEDAKMREVILAIRADEAHHRLVNHTLGS

538 MDLKDNPFEKGK

539

540 Figure A1.

541

542

543 


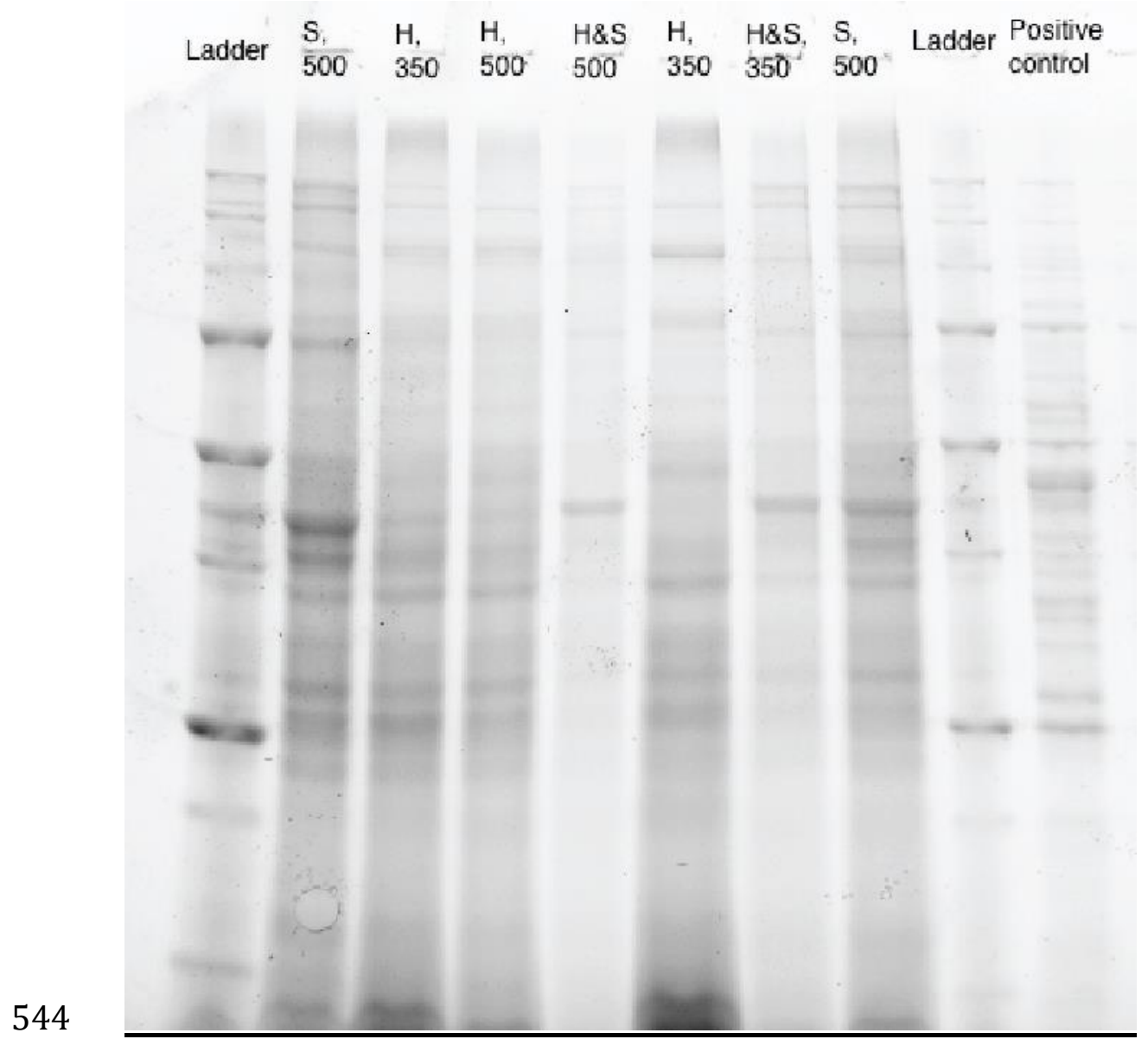

545

546

547

548 Figure A2.

549

550

551

552

553

554 
555

556

557

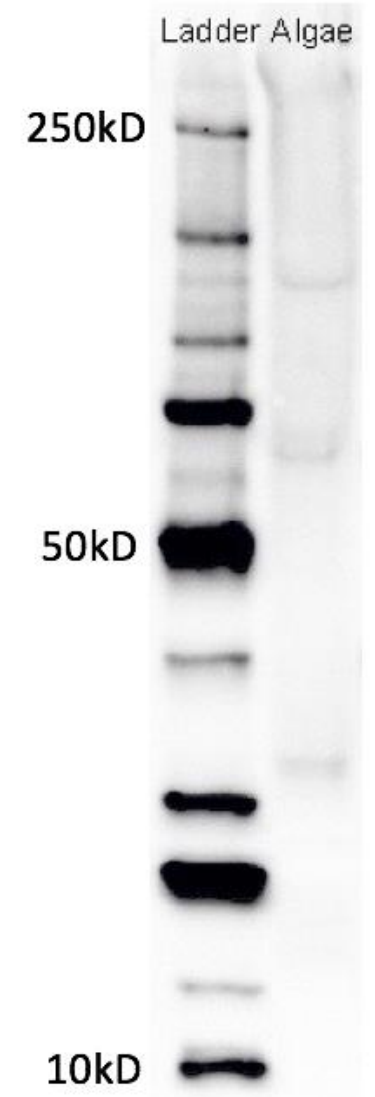

558

559

560

561

562 Figure A3. 


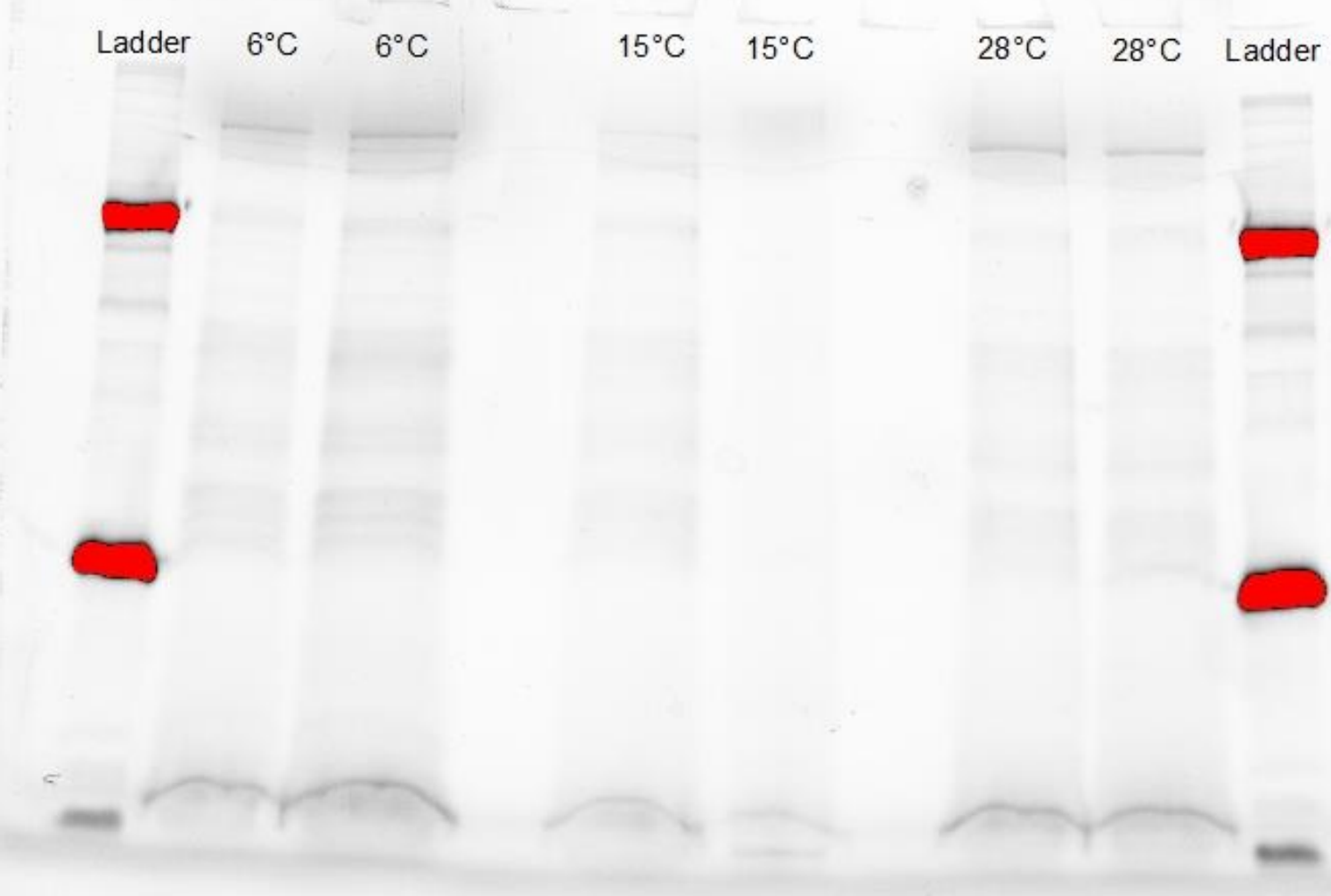

563

564

565

566

567

568

569

570 Figure A4.

571

572 


Ladder $\quad 6^{\circ} \mathrm{C} \quad 6^{\circ} \mathrm{C} \quad 15^{\circ} \mathrm{C} \quad 15^{\circ} \mathrm{C} \quad 28^{\circ} \mathrm{C} \quad 28^{\circ} \mathrm{C} \quad$ Ladder
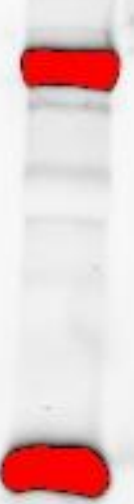

573

574

575

576

577

578

579 Figure A5.

580

581

582 
583 Table 1. Gene-specific primers designed for Tigriopus californicus AOX amplification.

584

\begin{tabular}{|l|l|l|l|}
\hline $\begin{array}{l}\text { Primer } \\
\text { Name }\end{array}$ & $\begin{array}{l}\text { Forward Primer } \\
\left.\text { Sequence } \mathbf{( 5 '}^{\prime} \rightarrow \mathbf{3}^{\prime}\right)\end{array}$ & $\begin{array}{l}\text { Reverse Primer } \\
\text { Sequence }\left(\mathbf{5}^{\prime} \rightarrow \mathbf{3}^{\prime}\right)\end{array}$ & $\begin{array}{l}\text { Expected } \\
\text { cDNA } \\
\text { Product } \\
\text { Size (bp) }\end{array}$ \\
\hline AOX1 & CCTGACTCAATGGCTGTTCA & CAAAATGACTTCCCGCATCT & 232 \\
\hline AOX2 & TGCCACAGATTTGTTGGGTA & TTCTCAACCTCCGTTCGTTT & 344 \\
\hline AOX3 & GGATCCACACTCTCCTGGAA & CTCAACCTCCGTTCGTTTTT & 503 \\
\hline
\end{tabular}


600 Table 2. Putative AOX sequences in copepods recovered using bioinformatics searches 601 of public databases.

\begin{tabular}{|c|c|c|c|c|c|}
\hline Order & Family & Species & $\begin{array}{l}\text { Representative } \\
\text { Accession } \\
\text { Number }\end{array}$ & $\begin{array}{l}\text { Iron- } \\
\text { binding } \\
\text { sites } \\
\text { present in } \\
\text { translated } \\
\text { AOX } \\
\text { protein }\end{array}$ & $\begin{array}{l}\text { Information on } \\
\text { Source } \\
\text { Material }\end{array}$ \\
\hline \multirow[t]{8}{*}{ Calanoida } & Acartiidae & Acartia tonsa & HAGX01001020 & All 4 & $\begin{array}{l}\text { All } \\
\text { developmental } \\
\text { stages }\end{array}$ \\
\hline & Calanidae & $\begin{array}{l}\text { Calanus } \\
\text { finmarchicus }\end{array}$ & GAXK01135432 & All 4 & $\begin{array}{l}\text { C5 } \\
\text { copepodite, } \\
\text { Trondheim, } \\
\text { Norway }\end{array}$ \\
\hline & & $\begin{array}{l}\text { Calanus } \\
\text { glacialis }\end{array}$ & HACJ01021827 & $\begin{array}{l}\text { IBS 1,2, } \\
\& 3\end{array}$ & $\begin{array}{l}\text { Whole } \\
\text { organism, } \\
\text { Norway }\end{array}$ \\
\hline & & $\begin{array}{l}\text { Neocalanus } \\
\text { flemingeri }\end{array}$ & GRUD01065088 & All 4 & Adult female \\
\hline & Caligidae & $\begin{array}{l}\text { Caligus } \\
\text { rogercresseyi }\end{array}$ & GAZX01011857 & $\begin{array}{l}\text { IBS 1,2, } \\
\& 3\end{array}$ & $\begin{array}{l}\text { Mixed } \\
\text { developmental } \\
\text { stages and } \\
\text { sexes }\end{array}$ \\
\hline & Metridinidae & $\begin{array}{l}\text { Pleuromamma } \\
\text { xiphias }\end{array}$ & GFCI01346245 & All 4 & $\begin{array}{l}\text { Whole adults, } \\
\text { both sexes, } \\
\text { BATS, Atlantic } \\
\text { Ocean }\end{array}$ \\
\hline & Pontellidae & $\begin{array}{l}\text { Labidocera } \\
\text { madurae }\end{array}$ & GFWO01190644 & All 4 & \\
\hline & Temoridae & $\begin{array}{l}\text { Eurytemora } \\
\text { affinis }\end{array}$ & GBGO01037152 & All 4 & Whole females \\
\hline \multirow[t]{3}{*}{ Cyclopoida } & Cyclopettidae & $\begin{array}{l}\text { Paracyclopina } \\
\text { nana }\end{array}$ & GCJT01014574 & All 4 & $\begin{array}{l}\text { Whole } \\
\text { animals, } \\
\text { Gangneung, } \\
\text { South Korea }\end{array}$ \\
\hline & Cyclopidae & $\begin{array}{l}\text { Eucyclops } \\
\text { serrulatus }\end{array}$ & GARW01011119 & All 4 & \\
\hline & Oithonidae & Oithona nana & FTRT01002078 & IBS $1 \& 2$ & \\
\hline
\end{tabular}




\begin{tabular}{|l|l|l|l|l|l|}
\hline Harpacticoida & Harpacticidae & $\begin{array}{l}\text { Tigriopus } \\
\text { californicus }\end{array}$ & JW502496 & All 4 & $\begin{array}{l}\text { San Diego } \\
\text { population }\end{array}$ \\
\hline & Harpacticidae & $\begin{array}{l}\text { Tigriopus } \\
\text { japonicas }\end{array}$ & GCHA01002206 & All 4 & $\begin{array}{l}\text { Whole } \\
\text { animals, } \\
\text { Gangneung, } \\
\text { South Korea }\end{array}$ \\
\hline & Harpacticidae & $\begin{array}{l}\text { Tigriopus sp. } \\
1 \text { SL-2012 }\end{array}$ & GDFW01016749 & All 4 & $\begin{array}{l}\text { Tidal pool, } \\
\text { Maxwell Bay, } \\
\text { Antarctica }\end{array}$ \\
\hline
\end{tabular}

602

6031 Trace sequence archive database at NCBI

$604{ }^{2}$ Nucleotide database at NCBI

References Compensation in Gene Expression. Molecular Biology and Evolution. 32, 613-622.

Barreto, F.S., Schoville, S.D., Burton, R.S., 2015b. Reverse genetics in the tide pool: knock-down of target gene expression via RNA interference in the copepod Tigriopus californicus. Molecular Ecology Resources. 15, 868-879.

Burton, R.S., Feldman, M.W., 1981. Population genetics of Tigriopus californicus. II. Differentiation among neighboring populations. Evolution. 35, 1192-1205.

Burton, R., Lee, B., 1994. Nuclear and mitochondrial gene genealogies and allozyme polymorphism across a major phylogeographic break in the copepod Tigriopus californicus. Proc. Of The National Academy Of Sciences. 91, 5197-5201.

Edmands, S., Deimler, J.K., 2004. Local adaptation, intrinsic coadaptation and the effects of environmental stress on interpopulation hybrids in the copepod Tigriopus californicus. J. of Experimental Marine Biology and Ecology. 303, 183-196.

El-Khoury, R., Dufour, E., Rak, M., Ramanantsoa, N., Grandchamp, N., Csaba, Z., Duvillie, B., Benit P., Gallego, J., Gressens, P., Sarkis, C., Jacobs, H.T., \& Rustin, P., 2013. Alternative oxidase expression in the mouse enables bypassing cytochrome $C$ oxidase blockade and limits mitochondrial ROS overproduction. PLoS Genetics. 9, e1003182.

633

El-Khoury, R., Kemppainen, K.K., Dufour, E. Szibor, M., Jacobs, H.T., Rustin, P., 2014. Engineering the alternative oxidase gene to better understand and counteract mitochondrial defects: state of the art and perspectives. Br. J. of Pharmacology. 171, 2243-2249. 
634 Fernandez-Ayala, D.J., Sanz, A., Vartiainen, S., Kemppainen, K.K., Babusiak, M., 635 Mustalahti, E., Costa, R., Tuomela, T., Zeviani, M., Chung, J., O'Dell, K.M.C., Rustin, P., 636 Jacobs, H.T., 2009. Expression of the Ciona intestinalis Alternative Oxidase (AOX) in

637 Drosophila Complements Defects in Mitochondrial Oxidative Phosphorylation. Cell 638 Metabolism. 9, 449-460.

Genova, M.L., 2014. Electron Transport in the Mitochondrial Respiratory Chain. In: Hohmann-Marriott, M.F. (Ed.), The Structural Basis of Biological Energy Generation, vol. 39. Advances in Photosynthesis and Respiration. Springer, Switzerland, pp. 401417.

644

Hakkaart, G.A., Dassa, E.P., Jacobs, H.T., Rustin, P., 2006. Allotopic expression of a mitochondrial alternative oxidase confers cyanide resistance to human cell respiration. EMBO Reports. 7, 341-345.

Hong, B.C., Shurin, J.B., 2015. Latitudinal variation in the response of tidepool copepods to mean and daily range in temperature. Ecology. 96, 2348-2359.

Kemppainen, K.K., Rinne, J., Sriram, A., Lakanmaa, M., Zeb, A., Tuomela, T., Popplestone, A., Singh, S., Sanz, A., Rustin, P., Jacobs, H.T., 2014. Expression of alternative oxidase in Drosophila ameliorates diverse phenotypes due to cytochrome oxidase deficiency. Human Molecular Genetics. 23, 2078-2093.

Lauritano, C., Procaccini, G., lanora, A., 2012. Gene expression patterns and stress response in marine copepods. Marine Environ. Res. 76, 22-31.

Liu M, Guo X., 2017. A novel and stress adaptive alternative oxidase derived from alternative splicing of duplicated exon in oyster Crassostrea virginica. Science Rep. 7, 10785.

May, B., Young, L., Moore, A.L., 2017. Structural insights into the alternative oxidases: are all oxidases made equal? Biochem. Soc. Trans. 45, 731-740.

McDonald, A.E., Vanlerberghe, G.C., 2004. Branched mitochondrial electron transport in the Animalia: presence of alternative oxidase in several animal phyla. IUBMB life. 56, 333-341.

McDonald, A.E., 2008. Alternative oxidase: an inter-kingdom perspective on the function and regulation of this broadly distributed 'cyanide-resistant' terminal oxidase. Functional Plant Biology. 35, 535-552.

McDonald, A.E., 2009. Alternative oxidase: what information can protein sequence comparisons give us?. Physiologia plantarum. 137, 328-341. 
McDonald, A.E., Vanlerberghe, G.C., Staples, J.F., 2009. Alternative oxidase in animals: unique characteristics and taxonomic distribution. J. of Experimental Biology. 212, 2627-2634.

681

682

McDonald, A.E., Gospodaryov, D.V., 2018. Alternative NAD(P)H dehydrogenase and

Neimanis, K., Staples, J.F., Hüner, N.P.A., McDonald, A.E., 2013. Identification, expression, and taxonomic distribution of alternative oxidases in non-angiosperm plants. Gene. 526, 275-286.

Raisuddin, S., Kwok, K.W., Leung, K.M., Schlenk, D., Lee, J.S., 2007. The copepod Tigriopus: A promising marine model organism for ecotoxicology and environmental genomics. Aquatic Toxicol. 83, 161-173.

Robertson, A., Schaltz, K., Neimanis, K., Staples, J.F., McDonald, A.E., 2016. Heterologous expression of the Crassostrea gigas (Pacific oyster) alternative oxidase in the yeast Saccharomyces cerevisiae. J. Bioenerg. Biomembr. 48, 509-520.

Rodriguez-Armenta, C., Uribe-Carvajal, S., Rosas-Lemus, M., Chiquete-Felix, N., Huerta-Ocampo, J.A., Muhlia-Almazan, A., 2018. Alternative mitochondrial respiratory chains from two crustaceans: Artemia franciscana nauplii and the white shrimp, Litopenaeus vannamei. J. Bioenerg. Biomembr. 50, 143-152.

Rogov, A.G., Sukhanova, E.I., Uralskaya, L.A., Aliverdieva, D.A., Zvyagilskaya, R.A., 2014. Alternative oxidase: distribution, induction, properties, structure, regulation, and functions. Biochem. 79, 1615-1634.

Schertl, P., Braun, H-P., 2014. Respiratory electron transfer pathways in plant mitochondria. Frontiers in Plant Science. 5, 163.

Sussarellu, R., Fabioux, C. Sanchez, M.C., Le Goïc, N., Lambert, C., Soudant, P., Moraga, D., 2012. Molecular and cellular response to short-term oxygen variations in the Pacific oyster Crassostrea gigas. J. of Experimental Marine Biology and Ecology. 412, 87-95.

Van Aken, O., Giraud, E., Clifton, R., Whelan, J., 2009. Alternative oxidase: a target and regulator of stress responses. Physiologia plantarum. 137, 354-361.

Vanlerberghe, G.C., 2013. Alternative oxidase: a mitochondrial respiratory pathway to maintain metabolic and signaling homeostasis during abiotic and biotic stress in plants. International J. of Molecular Sciences. 14, 6805-6847.

Yusseppone, M.S., Rocchetta, I., Sabatini, S.E., Luquet, C.M., del Carmen Rios de Molina, M., Held, C., Abele, D., 2018. Inducing the alternative oxidase forms part of the molecular strategy of anoxia survival in freshwater bivalves. Frontiers in Physiol. 9, 100. 
724 Zalutskaya, Z., Lapina, T., Ermilova, E. 2015. The Chlamydomonas reinhardtii

725 alternative oxidase 1 is regulated by heat stress. Plant Physiol. Biochem. 97, 229-234.

726

727 Zhang, H., Finiguerra, M., Dam, H. G., Huang, Y., Xu, D., Liu, G., Lin, S., 2013. An

728 improved method for achieving high-quality RNA for copepod transcriptomic studies. J. 729 of Experimental Marine Biology and Ecology. 446, 57-66. 